\title{
Molecular Detection of Hepatitis E Virus in Tibetan Swine
}

\author{
Gong Ga ${ }^{1,2}$ and SuoLang Sizhu ${ }^{2, *}$ \\ ${ }^{1}$ Institute of Tibet Plateau Ecology, Tibet Agriculture and Animal Husbandry University, \\ Nyingchi, China \\ ${ }^{2}$ Animal Science College, Tibet Agriculture and Animal Husbandry University, \\ Nyingchi, China
}

\begin{abstract}
A B S T R A C T
Hepatitis E virus (HEV) infection is a major potential public health problem in the world. HEV is also highly endemic in China. However, information is lacking on the prevalence of HEV infection in swine in Tibet of China, where raw pork and mixed farming of different species of domestic animals are consumed traditionally. In this study, 173 serum samples of Tibetan swine were tested for anti-HEV IgM and IgG antibodies by the ELISA. HEV RNA were measured in feces $(n=173)$, serum $(n=173)$ and tissue ((including liver, spleen, kidney and intestine, $n=21$ ) by nested RT-PCR and qRT-PCR. HEV antigens were detected in tissues by immunohistochemistry analysis. Overall, we found that that eight serum samples $(4.6 \%, 8 / 173)$ were positive to anti-HEV IgM antibody and Seventeen serum sample $(9.8 \%, 17 / 173)$ were positive for anti-HEV IgG antibody. The HEV RNA positive rate was of $4.6 \%$ $(8 / 173)$ in feces and serum. Moreover, the prevalence of HEV RNA was $9.5 \%(2 / 21)$ in swine liver, $4.8 \%$ $(1 / 21)$ in swine spleen, $9.5 \%(2 / 21)$ in swine kidney, $4.8 \%(1 / 21)$ in swine intestine and $14.3 \%(3 / 21)$ in swine pork. HEV antigens were abundantly observed in the portal of liver, medulla of spleen, glomeruli of kidney and villi of intestine of HEV infected swine. In conclusion, HEV was prevalent with high rate in swine population in Tibet province.
\end{abstract}
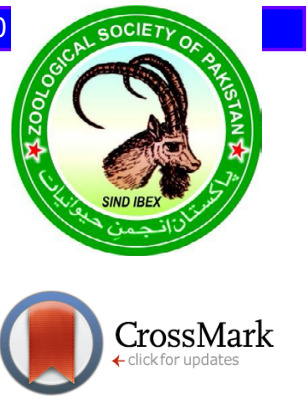

\section{INTRODUCTION}

$\mathrm{H}^{2}$ epatitis $\mathrm{E}$ virus (HEV) is a member of the family Hepeviridae within the genus Orthohepevirus (Aggarwal and Jameel, 2011; Kamar et al., 2012), with a 7.2-kb positive-sense RNA genome encoding three opening reading frames (ORFs) (Panda et al., 2007). Orthohepevirus A is classified into eight main genotypes (HEV 1-8) (Guerra et al., 2017), which genotypes 1 and 2 only infect humans and are mainly responsible for large waterborne outbreaks in developing countries (Lee et al., 2015), Genotype 3 and 4 are autochthonous in industrialized countries, which are zoonotic and is associated with sporadic. The Genotype 5 and 6 are isolated from wild boars in Japan (Takahashi et al., 2011). Genotype 7 and 8 are isolated from camel in Japan, which also can be transmitted to humans (Lee et al., 2016).

HEV is the causal agent of an acute self-limiting hepatitis in humans (Aggarwal, 2011), and caused more than 20 million people infection in the world (Rein et al., 2012). Moreover, HEV infection is associated with particularly high mortality rates in pregnant women up to 20-30\% (Mushahwar, 2008). HEV has been recognized as

\footnotetext{
* Corresponding author: xzsIsz@163.com

0030-9923/2020/0004-1563 \$ 9.00/0

Copyright 2020 Zoological Society of Pakistan
}

a zoonotic disease, which is mainly transmitted via fecaloral route, contaminated water, unhygienic food supplies and direct contact with the infected animals (El-Tras et al., 2013). HEV poses an important public health concern with cases of the disease definitively linked to handling of infected pigs, consumption of raw and undercooked animal meats, and animal manure contamination of drinking or irrigation water (Aggarwal et al., 2000; Meng, 2010).

The consumption of game meat has been identified as a factor associated with autochthonous HEV infection. Consumption of undercooked or raw organs or tissues from infected swine has been linked to numerous cases of hepatitis E worldwide (Miyashita et al., 2012; Moor et al., 2018; Yazaki et al., 2003). For example, the consumption of undercooked or raw pork in barbeque restaurant (Miyashita et al., 2012), the consumption of raw wild boar bile juice (Sonoda et al., 2004), the consumption of sausage (Corsican raw pig liver dish) (Christou and Kosmidou, 2013), also the consumption of undercooked or raw meat of boar (Li et al., 2005), deer (Tei et al., 2004) and camel (Lee et al., 2016) are identifying a positive association with hepatitis E infection. Recently, Zhang et al. (2017) demonstrated the presence of autochthonous HEV among people $(39.33 \%, 236 / 600)$ and pigs $(42.38 \%, 192 / 453)$ in Tibet, China through detecting the anti-HEV IgG.

However, the prevalence of HEV in swine was rarely reported in the Tibet, where mixed farming of domestic 
animals is a common and most studies related to HEV infection in these animals were restricted to serological surveys. Here, we aimed to assess the prevalence of HEV in swine by investigating HEV RNA in feces, serum, tissues, and anti-HEV IgG/IgM in serum and HEV antigen in tissues.

\section{MATERIALS AND METHODS}

\section{Sample collection}

In this study, the feces and serum sample $(n=173$, age $=1 \pm 0.2$ years) were collected from the two cities in Tibet, among which. The 100 sample were collected from Milin city (male, $n=84$, female, $n=16$,) and the other 73 samples were collected from Linzhi city (male, $n=51$, female $n=22$ ). These 173 samples also contained 21 tissues including liver $(\mathrm{n}=21)$, spleen $(\mathrm{n}=21)$, kidney $(\mathrm{n}=21)$, intestine $(n=21)$, and pork $(n=21)$. The samples were stored at $-80^{\circ} \mathrm{C}$ until use. Tissues were fixed in $10 \%$ neutral buffered formalin or stored at $-80^{\circ} \mathrm{C}$. These samples were collected under permission of the local government.

\section{Determination of anti-HEV antibodies}

Serum samples were tested for the presence of HEVspecific IgG and IgM antibodies by using commercial ELISA kits (Wantai, China) according to the manufacturer's instructions.

\section{Detection of HEV RNA}

Stool specimens were suspended at $10 \% \mathrm{w} / \mathrm{v}$ in phosphate-buffered saline (PBS; $\mathrm{pH} 7.4$ ), containing $0.01 \%$ diethyl pyrocarbonate (DEPC), and centrifuged at $12000 \times \mathrm{g}$ for $10 \mathrm{~min}$. Tissue samples were homogenized grinded by liquid nitrogen. Total RNA was extracted from the stool supernatant, serum and tissue homogenate, respectively, using TRIzol ${ }^{\circ}$ reagent (Invitrogen, USA) according to the manufacturer's instructions. Reverse transcription (RT) was performed using a reverse transcriptase kit (AMV, Takara, Japan) according to the manufacturer's directions. A 348 nt amplicon from HEV ORF2 was amplified by RTnested PCR as described previously (Huang et al., 2002).

Viral titer quantification by quantitative real-time PCR

The viral titer of HEV in serum, feces and tissues was quantified using SYBR green-based quantitative RTPCR (qRT-PCR) with HEV-specific primers as described previously (Huang et al., 2002, 2016).

\section{Immunohistochemistry analysis}

Tissue samples were fixed in $10 \%$ neutral buffered formalin, embedded in paraffin and cut into $3 \mu \mathrm{m}$ serial sections. For immunohistochemistry, tissues were deparaffinated, hydrated, water bath-heated for antigen retrieval and blocked with the addition of 3\% hydrogen peroxide for $15 \mathrm{~min}$. Sections were then incubated overnight at $4^{\circ} \mathrm{C}$ with a $1: 125$ dilution of mouse anti-Hepatitis E monoclonal antibody (Millipore; MAB8003, USA), washed with PBS and stained for visualization incubated 1 $h$ at $37^{\circ} \mathrm{C}$ with HRP-labelled secondary antibody (Abcom; ab6789, USA). The reaction was visualized using DAB as chromogen. The slides were sealed with neutral balsam, inspected, and photographed under a microscope.

\section{Phylogenetic analysis}

The nucleotide sequences of the amplified PCR products and prototypes of different genotypes of $\mathrm{HEV}$ strains were aligned using the MEGA5.1 program. The genomic sequences of prototype HEV strains were then obtained from the GenBank database. The standard classification of HEV genotypes and subtypes were based from previous studies (Smith et al., 2014, 2016). Phylogenetic tree based on the HEV ORF2 partial sequences (348 bp) generated using the Neighbor-Joining method (1000 bootstrap replicates) of the MEGA 5.1 program. The identity between the nucleotide sequences was calculated using the MegAlign program (DNA star package version 5.03), according to the previous studies (Smith et al., 2014, 2016).

\section{Statistical analysis}

Data are presented as mean \pm SD. Statistical analysis was performed using GraphPad Prism software and $\mathrm{P}$ values were calculated using Student's t-test to determine the significance of differences between two or more groups, with a 0.05 level of probability $(\mathrm{P}<0.05)$ considered statistically significant.

\section{RESULTS}

\section{Seroprevalence of HEV in Tibetan swine}

To investigate the seroprevalence of HEV in Tibetan swine, serum was collected to test the anti-HEV antibody. Eight serum samples $(4.6 \%, 8 / 173)$ were positive for HEV IgM antibody and seventeen serum sample $(9.83 \%$, 17/173) were positive for HEV IgG antibody (Fig. 1A), which was significantly lower than the seroprevalence of swine in Xinjiang $(84.6 \%, 66 / 78)$ (Fu et al., 2010) and in India (38.8\%, 26/67) (Begum et al., 2010).

We also found that the prevalence rate of anti-HEV $\operatorname{IgM}$ and $\mathrm{IgG}$ antibodies were different in the two regions. In Milin city, the prevalence rate of anti-HEV IgM antibody was $5.0 \%(5 / 100)$ (male was $4.7 \%, 4 / 84$, female was $6.2 \%$, $1 / 16, \mathrm{p}=1.0)$, but the prevalence rate of anti-HEV IgM antibody was $4.1 \%(3 / 73)$ in Linzhi city (male was $3.9 \%$, 
$1 / 52$, female was $4.5 \%, 1 / 22, \mathrm{p}=0.5$ ) (Fig. 1B). Moreover, the prevalence rate of anti-HEV IgG antibody was $11.0 \%$ $(11 / 100)$ in Milin city (male was $10.7 \%, 9 / 84$, female was $12.5 \%, 2 / 16, \mathrm{p}=1.0$ ), the prevalence rate of anti-HEV IgM antibody was $8.2 \%(6 / 73)$ in Linzhi city (male was $7.8 \%$, $4 / 52$, female was $9.1 \%, 2 / 22, p=1.0$ ) (Fig. 1B). Of note, there is no significant difference in the positive rate of antiHEV IgM and IgG antibodies in gender between the two cities $(\mathrm{p}>0.05)$.

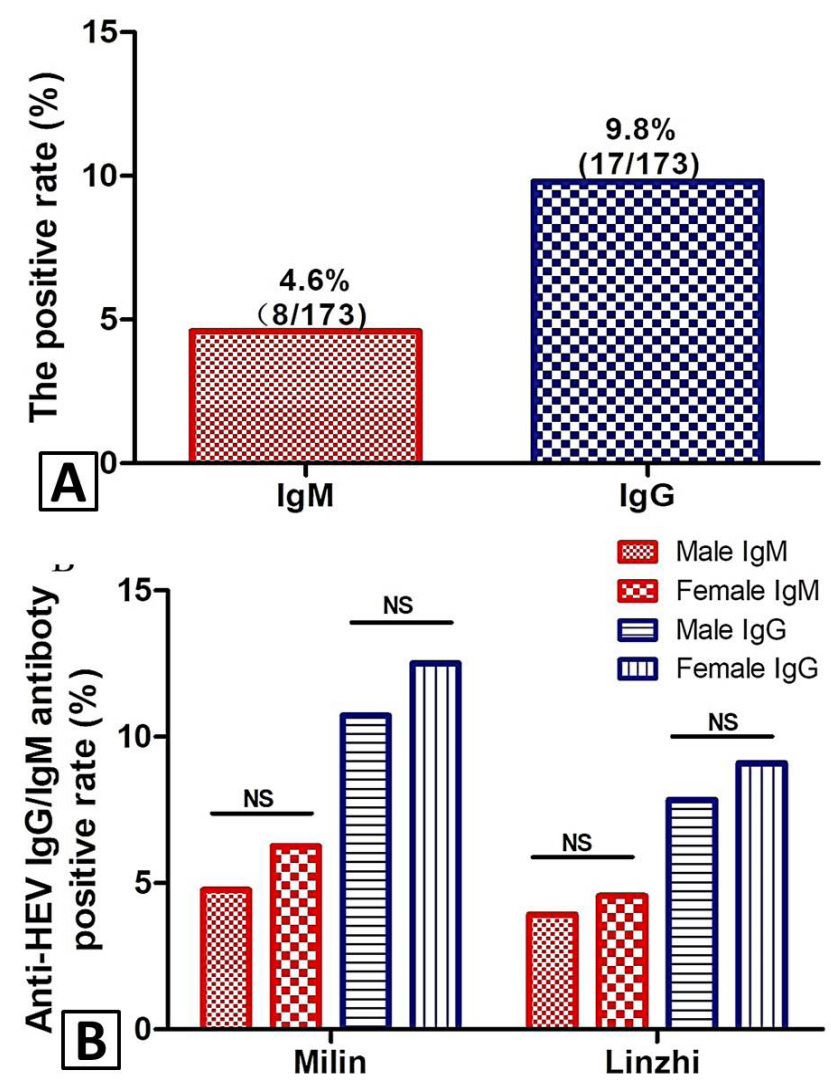

Fig. 1. Seroprevalence of HEV in Tibetan swine. A, the positive rate of anti-HEV IgM and IgG antibodies in serum of Tibetan swine, China; B, the different of anti-HEV IgM antibody and anti-HEV IgG antibody positive rate between the gender in two cities; $\mathbf{C}$, the different of anti-HEV IgG antibody positive rate between the gender in two cities.

Detection of HEV RNA in Tibetan swine feces, serum, tissues

At the same time, we also measured the prevalence of HEV RNA in swine feces and serum samples. Results indicated that the HEV RNA positive rate was up to $4.6 \%$ $(8 / 173)$ in feces and serum (Fig. 2A). The positive rate of HEV RNA was 5.0\% (5/100) in feces and serum in Milin city (male was $4.7 \%, 4 / 84$, female was $6.2 \%, 1 / 16, p=1.0$ ), while the positive rate of HEV RNA was $4.1 \%(3 / 73)$ in feces and serum in Linzhi city (male was 3.9\%, 1/52, female was $4.5 \%, 1 / 22, \mathrm{p}=0.5$ ), which was consistent with the anti-HEV IgM antibody, and the HEV RNA positive rate also has no significant difference in gender between the two cities (Fig. 2B). At addition, those result consisted with the study by Li et al. (2011) reported, but are lower than swine in Yunnan province 7.8\% (20/256) (Shu et al., 2014), 8.3\% (5/60) (Li et al., 2011), in India 8.7\% (14/160) (Bansal et al., 2017).

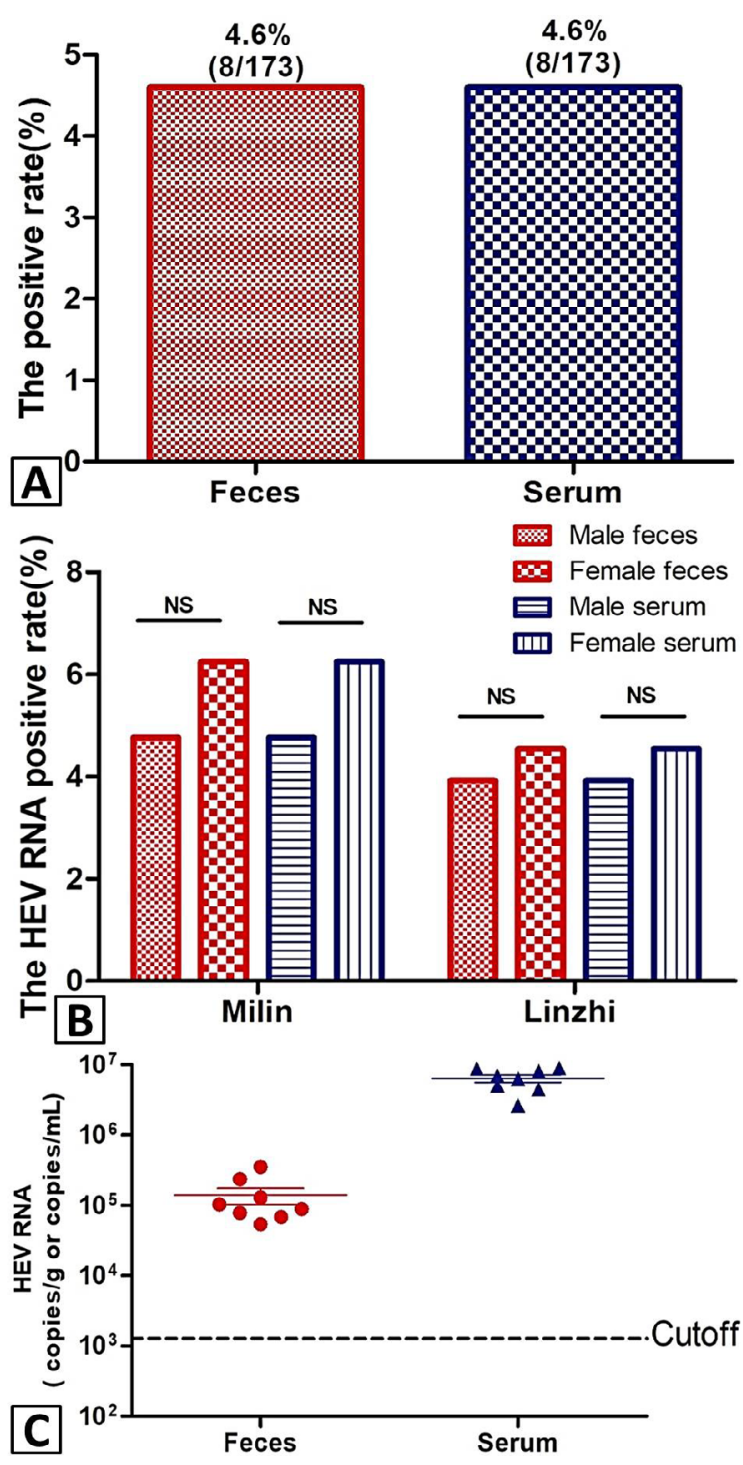

Fig. 2. Prevalence of HEV infection in Tibetan swine. A, the positive rate of HEV RNA in feces and serum samples of Tibetan swine, China; B, the different of HEV RNA positive rate in feces and serum between the gender in two cities; $\mathbf{C}$, the virus titer in feces and serum of Tibetan pigs, China. Unit for feces samples, copies/g; Unit for serum samples, copies $/ \mathrm{ml}$. 
Meanwhile, we found the HEV titers were difference in feces and serum, the viral titer up to $1.3 \times 10^{5} \pm 9.7 \times 10^{4} \mathrm{copies} / \mathrm{g}$ in feces, but the viral titer is higher in serum than that in the feces which was up to $6.4 \times 10^{6} \pm 2.1 \times 10^{6} \mathrm{copies} / \mathrm{ml}$ (Fig. 2C).

Moreover, we also found that the HEV RNA positive rate was $9.5 \%(2 / 21)$ in swine liver, $4.8 \%(1 / 21)$ in swine spleen, $9.5 \%(2 / 21)$ in swine kidney, $4.8 \%(1 / 21)$ in swine intestine and $14.3 \%(3 / 21)$ in swine pork (Fig. 3A). Because of the limited samples, some percentages might only be of relative significance. Those results are different with the pork products in Yunnan province, which reported that the HEV RNA positive rate up to $8.3 \%$ in liver, $33.3 \%$ in spleen, $18.7 \%$ in intestine and $33.3 \%$ in pork (Hao et al., 2018). At addition, the HEV title was also detected in swine tissue, the virus titer was $5.7 \times 10^{5} \mathrm{copies} / \mathrm{g}$ in liver, $5.1 \times 10^{5}$ copies $/ \mathrm{g}$ in spleen, $2.1 \times 10^{5}$ copies $/ \mathrm{g}$ in kidney, $3.1 \times 10^{5} \mathrm{copies} / \mathrm{g}$ in intestine and $5.0 \times 10^{5} \mathrm{copies} / \mathrm{g}$ in pork (Fig. 3B).

HEV antigens in the liver, spleen, kidney and intestine of Tibetan swine

Consumption of raw or undercooked meat has been confirmed to be associated with HEV infection (Christou and Kosmidou, 2013; Li et al., 2005; Miyashita et al., 2012; Tei et al., 2004). In this study, HEV antigens were abundantly observed in the portal of liver, medulla of spleen, glomeruli of kidney and villi of intestine in HEV infected swine, which clearly demonstrated the risk of HEV infection (Fig. 4).

High homology of swine HEV with human HEV and swine HEV strains

Homology analysis indicated that the HEV isolates from the tested pork products was genotype $4 \mathrm{HEV}$ based on partial ORF2 sequences (348 bp). Moreover, these HEV strains shared high similarity of homology (99\%-
$100 \%$ ) with the human HEV and swine HEV strain, which was suggested that maybe the swine strain is source of infection of human HEV.

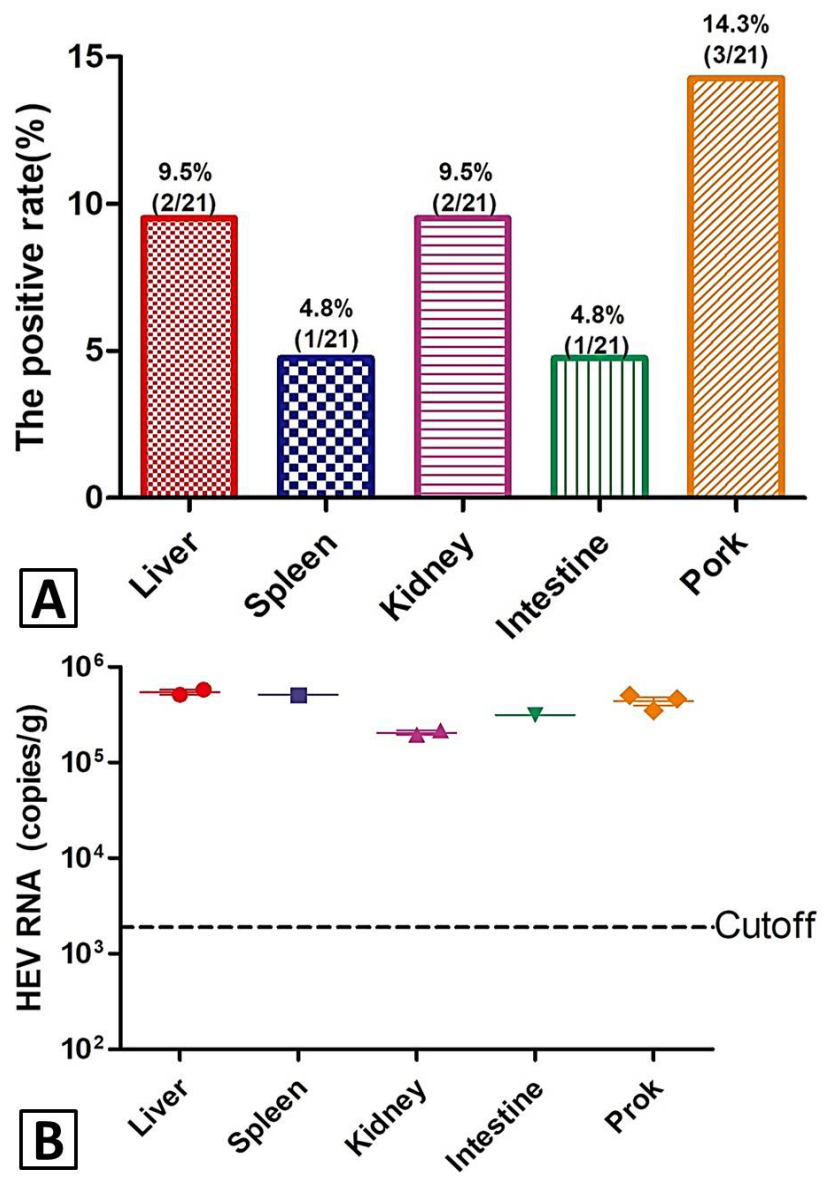

Fig. 3. HEV infection in swine tissues. A, the positive rate of HEV RNA in tissue of Tibetan swine, China. B, the virus titer in tissue of Tibetan pigs, China. Unit for tissue samples, copies/g.

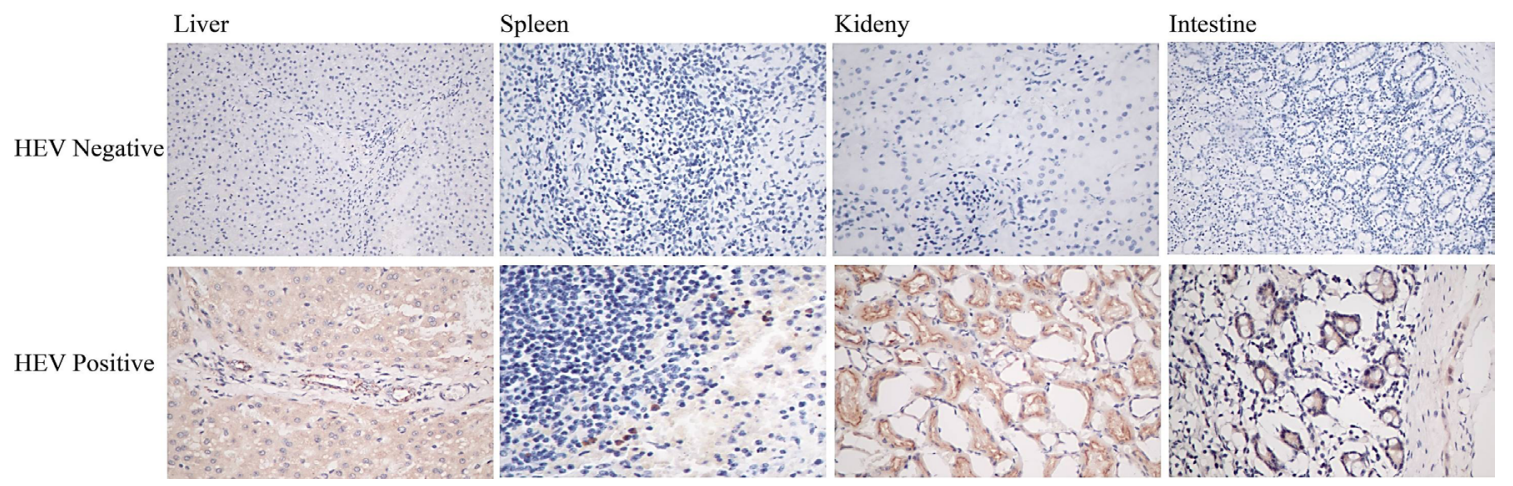

Fig. 4. Immunohistochemical analyses of swine tissue. Immunohistochemical analyses (IHC) for HEV antigens in tissue samples of Tibetan swine $(400 \times)$, including liver, spleen, intestine and kidney. 


\section{DISCUSSION}

HEV represents a significant health problem, especially in the developing countries like China (Jia et al., 2014). Zoonotic transmission of HEV has been firmly confirmed from swine, cow or camel to human or nonhuman primate by raw or uncooked meat or milk (Berto et al., 2012; Lee et al., 2016; Sonoda et al., 2004). However, limited information on $\mathrm{HEV}$ infection in highland inhabitants (Tibet, average elevation $>3000 \mathrm{~m}$ ) in China is available. Whether the Tibetan swine are susceptive of HEV is unclear?

In this study, the high positive rate of anti-HEV IgM and IgG antibodies were found in serum of Tibet swine, and the two studied cities showed no significant difference in HEV prevalence, which suggested that the HEV infection are popular in Tibet that was further confirmed by the high positive rate of HEV RNA in feces and serum.

Foodborne cases of hepatitis $\mathrm{E}$ in humans are increasingly common and likely underestimated in the medical community (Nan et al., 2017; Okano et al., 2014). Sporadic and cluster cases of hepatitis E occur after consumption of undercooked or raw animal meats (Okano et al., 2014; Tei et al., 2003). In this study, beside liver, HEV RNA and HEV antigens were also detected in several tissues including spleen, kidney, intestine and pork with higher titer than feces, which also reflected the extra-hepatic sites of HEV replication and indicated the high risk of consuming undercooked or raw swine. More importantly, raw pork consumption is popular and traditional in these regions. Thus, more attention should be paid to fully assess the impact of HEV infection on local people and effective measures should be taken to control the spread of HEV.

\section{CONCLUSIONS}

The high prevalence of anti-HEV IgM and IgG antibodies, HEV RNA and HEV antigens in swine samples collected in Tibet suggested HEV was prevalent in swine group in Tibet.

\section{ACKNOWLEDGMENTS}

This study was funded by China Agricultural University-Tibet Agriculture and Animal Husbandry College Cooperation Project (Grant Number 2018); Natural Science Foundation of Tibet province (Grant Number XZ2019ZRG-65); Funding for Preventive Veterinary Research in Tibet Agriculture and Animal Husbandry University (Grant Number 2017), Central Government Supports Special Funds for the Development of Local
Colleges and Universities in China (Grant Number 2016397) and Tibet Agriculture and Animal Husbandry College Awards Fund (Grant Number 2019). The funders had no role in study design, data collection and analysis, decision to publish, or preparation of the manuscript.

\section{Statement of conflict of interest}

The authors declare no conflict of interest.

\section{REFERENCES}

Aggarwal, R., 2011. Clinical presentation of hepatitis E. Virus Res., 161: 15-22. https://doi.org/10.1016/j. virusres.2011.03.017

Aggarwal, R. and Jameel, S., 2011. Hepatitis E. Hepatology, 54: 2218-2226. https://doi. org/10.1002/hep. 24674

Aggarwal, R., Kini, D., Sofat, S., Naik, S.R. and Krawczynski, K., 2000. Duration of viraemia and faecal viral excretion in acute hepatitis E. Lancet, 356: 1081-1082. https://doi.org/10.1016/S01406736(00)02737-9

Bansal, M., Kaur, S., Deka, D., Singh, R. and Gill, J.P.S., 2017. Seroepidemiology and molecular characterization of hepatitis $\mathrm{E}$ virus infection in swine and occupationally exposed workers in Punjab, India. Zoon. Publ. Hlth., 64: 662-672. https://doi.org/10.1111/zph.12363

Begum, N., Polipalli, S.K., Husain, S.A. and Kar, P., 2010. Molecular analysis of swine hepatitis E virus from north India. Indian J. med. Res., 132: 504-508.

Berto, A., Martelli, F., Grierson, S. and Banks, M., 2012. Hepatitis E virus in pork food chain, United Kingdom, 2009-2010. Emerg. Infect. Dis., 18: 13581360. https://doi.org/10.3201/eid1808.111647

Christou, L. and Kosmidou, M., 2013. Hepatitis E virus in the Western world-a pork-related zoonosis. Clin. Microbiol. Infect., 19: 600-604. https://doi. org/10.1111/1469-0691.12214

El-Tras, W.F., Tayel, A.A. and El-Kady, N.N., 2013. Seroprevalence of hepatitis $\mathrm{E}$ virus in humans and geographically matched food animals in Egypt. Zoon. Publ. Hlth., 60: 244-251. https://doi. org/10.1111/j.1863-2378.2012.01516.x

Fu, H., Li, L., Zhu, Y., Wang, L., Geng, J., Chang, Y., Xue, C., Du, G., Li, Y. and Zhuang, H., 2010. Hepatitis $\mathrm{E}$ virus infection among animals and humans in Xinjiang, China: Possibility of swine to human transmission of sporadic hepatitis $\mathrm{E}$ in an endemic area. Am. J. trop. Med. Hyg., 82: 961-966. https://doi.org/10.4269/ajtmh.2010.09-0689

Guerra, J., Kampa, K.C., Morsoletto, D.G.B., Junior, 
A.P. and Ivantes, C.A.P., 2017. Hepatitis E: A literature review. J. Clin. Transl. Hepatol., 5: 376383. https://doi.org/10.14218/JCTH.2017.00012

Hao, X., Cao, W., Situ, J., Zhao, Y., Huang, F. and Yu, W., 2018. Hepatitis E virus detected in pork products. Fd. environ. Virol., 10: 391-393.

Huang, F., Li, Y., Yu, W., Jing, S., Wang, J., Long, F., He, Z., Yang, C., Bi, Y., Cao, W., Liu, C., Hua, X. and Pan, Q., 2016. Excretion of infectious hepatitis $\mathrm{E}$ virus into milk in cows imposes high risks of zoonosis. Hepatology, 64: 350-359. https://doi. org/10.1002/hep. 28668

Huang, F.F., Haqshenas, G., Guenette, D.K., Halbur, P.G., Schommer, S.K., Pierson, F.W., Toth, T.E. and Meng, X.J., 2002. Detection by reverse transcription-PCR and genetic characterization of field isolates of swine hepatitis $\mathrm{E}$ virus from pigs in different geographic regions of the United States. J. clin. Microbiol., 40: 1326-1332. https://doi. org/10.1128/JCM.40.4.1326-1332.2002

Jia, Z., Yi, Y., Liu, J., Cao, J., Zhang, Y., Tian, R., Yu, T., Wang, H., Wang, X., Su, Q., Zhou, W., Cui, F., Liang, X. and Bi, S., 2014. Epidemiology of hepatitis $\mathrm{E}$ virus in China: Results from the Third National Viral Hepatitis Prevalence Survey, 2005-2006. PLoS One, 9: e110837. https://doi. org/10.1371/journal.pone.0110837

Kamar, N., Bendall, R., Legrand-Abravanel, F., Xia, N.S., Ijaz, S., Izopet, J. and Dalton, H.R., 2012. Hepatitis E. Lancet, 379: 2477-2488. https://doi. org/10.1016/S0140-6736(11)61849-7

Lee, G.H., Tan, B.H., Teo, E.C., Lim, S.G., Dan, Y.Y., Wee, A., Aw, P.P., Zhu, Y., Hibberd, M.L., Tan, C.K., Purdy, M.A. and Teo, C.G., 2016. Chronic infection with camelid hepatitis $\mathrm{E}$ virus in a liver transplant recipient who regularly consumes camel meat and milk. Gastroenterology, 150: 355-357. https://doi.org/10.1053/j.gastro.2015.10.048

Lee, G.Y., Poovorawan, K., Intharasongkroh, D., SaNguanmoo, P., Vongpunsawad, S., Chirathaworn, C. and Poovorawan, Y., 2015. Hepatitis E virus infection: Epidemiology and treatment implications. World J. Virol., 4: 343-355. https://doi.org/10.5501/ wjv.v4.i4.343

Li, T.C., Chijiwa, K., Sera, N., Ishibashi, T., Etoh, Y., Shinohara, Y., Kurata, Y., Ishida, M., Sakamoto, S., Takeda, N. and Miyamura, T., 2005. Hepatitis E virus transmission from wild boar meat. Emerg. Infect. Dis., 11: 1958-1960. https://doi.org/10.3201/ eid1112.051041

Li, W., Shu, X., Pu, Y., Bi, J., Yang, G. and Yin, G., 2011. Seroprevalence and molecular detection of hepatitis E virus in Yunnan Province, China. Arch Virol., 156: 1989-1995. https://doi.org/10.1007/ s00705-011-1089-6

Meng, X.J., 2010. Hepatitis E virus: Animal reservoirs and zoonotic risk. Vet. Microbiol., 140: 256-265. https://doi.org/10.1016/j.vetmic.2009.03.017

Miyashita, K., Kang, J.H., Saga, A., Takahashi, K., Shimamura, T., Yasumoto, A., Fukushima, H., Sogabe, S., Konishi, K., Uchida, T., Fujinaga, A., Matsui, T., Sakurai, Y., Tsuji, K., Maguchi, H., Taniguchi, M., Abe, N., Fazle Akbar, S.M., Arai, M. and Mishiro, S., 2012. Three cases of acute or fulminant hepatitis $\mathrm{E}$ caused by ingestion of pork meat and entrails in Hokkaido, Japan: Zoonotic food-borne transmission of hepatitis $\mathrm{E}$ virus and public health concerns. Hepatol. Res., 42: 870-878. https://doi.org/10.1111/j.1872-034X.2012.01006.x

Moor, D., Liniger, M., Baumgartner, A. and Felleisen, R., 2018. Screening of ready-to-eat meat products for hepatitis E virus in Switzerland. Fd. environ. Virol., 10: 263-271.

Mushahwar, I.K., 2008. Hepatitis E virus: Molecular virology, clinical features, diagnosis, transmission, epidemiology, and prevention. J. med. Virol., 80: 646-658. https://doi.org/10.1002/jmv.21116

Nan, Y., Wu, C., Zhao, Q. and Zhou, E.M., 2017. Zoonotic hepatitis E virus: An ignored risk for public health. Front. Microbiol., 8: 2396. https:// doi.org/10.3389/fmicb.2017.02396

Okano, H., Takahashi, M., Isono, Y., Tanaka, H., Nakano, T., Oya, Y., Sugimoto, K., Ito, K., Ohmori, S., Maegawa, T., Kobayashi, M., Nagashima, S., Nishizawa, T. and Okamoto, H., 2014. Characterization of sporadic acute hepatitis $\mathrm{E}$ and comparison of hepatitis E virus genomes in acute hepatitis patients and pig liver sold as food in Mie, Japan. Hepatol. Res., 44: e63-e76. https://doi. org/10.1111/hepr.12216

Panda, S.K., Thakral, D. and Rehman, S., 2007. Hepatitis E virus. Rev. Med. Virol., 17: 151-180. https://doi.org/10.1002/rmv.522

Rein, D.B., Stevens, G.A., Theaker, J., Wittenborn, J.S. and Wiersma, S.T., 2012. The global burden of hepatitis E virus genotypes 1 and 2 in 2005 . Hepatology, 55: 988-997. https://doi.org/10.1002/ hep. 25505

Shu, X., Duan, X., Song, C., Li, J., Jiang, L., Yin, G. and $\mathrm{Li}, \mathrm{W} ., 2$ 2014. Genetic heterogeneity of swine hepatitis E virus isolates from Yunnan province, China in 2011-2012. Virol. J., 11: 162. https://doi. org/10.1186/1743-422X-11-162

Smith, D.B., Simmonds, P., Izopet, J., Oliveira-Filho, 
E.F., Ulrich, R.G., Johne, R., Koenig, M., Jameel, S., Harrison, T.J., Meng, X.J., Okamoto, H., Van der Poel, W.H. and Purdy, M.A., 2016. Proposed reference sequences for hepatitis $\mathrm{E}$ virus subtypes. J. gen. Virol., 97: 537-542. https://doi.org/10.1099/ jgv.0.000393

Smith, D.B., Simmonds, P., Jameel, S., Emerson, S.U., Harrison, T.J., Meng, X.J., Okamoto, H., Van der Poel, W.H. and Purdy, M.A., 2014. Consensus proposals for classification of the family Hepeviridae. J. gen. Virol., 95: 2223-2232. https:// doi.org/10.1099/vir.0.068429-0

Sonoda, H., Abe, M., Sugimoto, T., Sato, Y., Bando, M., Fukui, E., Mizuo, H., Takahashi, M., Nishizawa, T. and Okamoto, H., 2004. Prevalence of hepatitis $\mathrm{E}$ virus (HEV) Infection in wild boars and deer and genetic identification of a genotype $3 \mathrm{HEV}$ from a boar in Japan. J. clin. Microbiol., 42: 53715374. https://doi.org/10.1128/JCM.42.11.53715374.2004

Takahashi, M., Nishizawa, T., Sato, H., Sato, Y., Jirintai, Nagashima, S. and Okamoto, H., 2011. Analysis of the full-length genome of a hepatitis $\mathrm{E}$ virus isolate obtained from a wild boar in Japan that is classifiable into a novel genotype. J. gen. Virol., 92:
902-908. https://doi.org/10.1099/vir.0.029470-0

Tei, S., Kitajima, N., Ohara, S., Inoue, Y., Miki, M., Yamatani, T., Yamabe, H., Mishiro, S. and Kinoshita, Y., 2004. Consumption of uncooked deer meat as a risk factor for hepatitis $\mathrm{E}$ virus infection: An ageand sex-matched case-control study. J. med. Virol., 74: 67-70. https://doi.org/10.1002/jmv.20147

Tei, S., Kitajima, N., Takahashi, K. and Mishiro, S., 2003. Zoonotic transmission of hepatitis $\mathrm{E}$ virus from deer to human beings. Lancet, 362: 371-373. https://doi.org/10.1016/S0140-6736(03)14025-1

Yazaki, Y., Mizuo, H., Takahashi, M., Nishizawa, T., Sasaki, N., Gotanda, Y. and Okamoto, H., 2003. Sporadic acute or fulminant hepatitis $\mathrm{E}$ in Hokkaido, Japan, may be food-borne, as suggested by the presence of hepatitis $\mathrm{E}$ virus in pig liver as food. J. gen. Virol., 84: 2351-2357. https://doi. org/10.1099/vir.0.19242-0

Zhang, L., Li, K., Huang, S., Liu, D., Rehman, M.U., Lan, Y., Zhang, H., Wang, L., Hao, Y., Iqbal, M.K., Mehmood, K., Chamba, Y. and Li, J., 2017. Seroprevalence and risk factors associated with hepatitis $\mathrm{E}$ virus infections among people and pigs in Tibet, China. Acta Trop., 172: 102-106. https:// doi.org/10.1016/j.actatropica.2017.04.033 